\title{
Social Studies and Civil Society: Making the Case to Take on Neoliberalism
}

\author{
Paul Orlowski \\ University of Saskatchewan
}

\begin{abstract}
The biggest threat to civil society in Canada and the United States is the economic doctrine known as neoliberalism. Sometimes referred to as the corporate agenda, this philosophy supports the deregulation of industry, the privatization of the commons, the weakening of workers' rights, and corporate tax cuts. Acknowledging that teaching is a political act, this paper makes a case for social studies and history teachers to develop pedagogy that lifts the hegemonic veil for students. Progressive values--progressive tax reform, support for workers, strengthening social welfare, and regulating industry--are the antithesis of neoliberalism. After describing the effects of neoliberalism today, the paper highlights important victories for working- and middle-class citizens taken for a stronger civil society in the pasts of both countries based on Keynesian economics and social democratic values. The paper outlines a pedagogical approach for social studies teachers based upon ideology critique, critical media literacy, and reframing of neoliberal discourses with progressive ones. Deconstructing hegemony is the crucial component of this critical pedagogy.
\end{abstract}

Keywords: social studies education; neoliberalism; ideology critique; critical media literacy; deconstructing hegemony 


\section{Social Studies and Civil Society: Making the Case to Take on Neoliberalism}

In the three decades prior to the recent economic downturn, wage gaps widened and household income inequality increased in a large majority of OECD countries. This occurred even when countries were going through a period of sustained economic and employment growth. (OECD, 2011, p. 1)

Since the 1980s, Canadians have been inundated with a powerful discursive formation that touts corporate tax cuts, deregulation of industry, attacks on workers and collective bargaining rights, privatization of the commons, and free markets (Orlowski, 2011). This economic doctrine has a name-neoliberalism — and since the 1980s, it has replaced Keynesian economics to become the dominant economic paradigm in most Western nations. Neoliberalism shares with classical liberalism a stance for free markets. The extreme form of classical liberalism is referred to as laissez faire economics, a system that is very much similar to neoliberalism, as will be discussed later.

For almost 30 years I have been an educator, splitting those years as a high school teacher and as a teacher educator at a large university in Western Canada. Throughout this period, teaching for political consciousness has always been my major objective. To this end, I believe that social studies and civic studies teachers have an important role to play in educating students about democracy. ${ }^{4}$ Democracy, of course, is not only referring to our electoral system but also it is, indeed, about having more voices heard from diverse social groups, including the marginalized. Consequently, teachers need to create spaces to have counterhegemonic perspectives heard. They need to highlight why massive and diverse social movements of resistance are arising more often than in past years. Teachers need to develop pedagogy that focuses on developing informed citizens who are willing to participate in these democratic initiatives, or at least understand these movements and the conditions that give rise to them. In my experience, once students understand political ideology, and why widespread social change occurs, they soon begin to comprehend the deleterious effects of the corporate agenda on civil society. Recent social movements such as Occupy Wall Street and Idle No More are direct reactions to the socioeconomic conditions resulting from this neoliberal agenda.

In this article, I make a case for social studies teachers to take on neoliberalism and suggest pedagogy on how to do this. In the first section, I will briefly discuss the purpose of social studies in Canada. Second, after a short description of neoliberalism and economic laissez faire economic policy, I will briefly discuss Keynesian economics and some of the victories for the middle and working classes during the Post World War II period up until the 1970s in Canada. Third, recent government and corporate behaviour in Canada will be highlighted to demonstrate the extent to which neoliberalism is replacing the policies of Keynesian economics, a model that gave rise to the social welfare state. ${ }^{2}$ A short discussion about what class warfare looks like follows this. In the final section, I will outline pedagogy I have found to be effective at both the high school and university levels that deconstructs neoliberal hegemony.

This article eschews any pretense of neutrality. It is not a call for a leftist brainwashing, however, in that its primary goal is to make a case for social studies educators to teach about the effects of neoliberalism on the social lives of the majority of Canadians. If the article takes a stance at all, it is in making the case that in order to teach for a stronger democracy, students must have a political consciousness. 


\section{The Purpose of Social Studies}

\section{Those who tell the stories also hold the power. (Plato)}

Some people contend that teaching for a political consciousness is outside of what teachers should do in the classroom. This perspective, however, is problematic for two reasons: First, everything about teaching is political, including the topics covered, the ways they are taught, and the assessment strategies used; and second, it ignores the long accepted purpose of social studies. The most important objective in every state-sanctioned social studies curriculum that I have examined is to teach about democracy and citizenship. Indeed, in British Columbia, the province I am most familiar with, every version of the social studies curriculum, beginning in 1941 up until and including the document currently used in every B.C. high school classroom, foregrounds this goal in the mission statement (Orlowski, 2011). Hence, teaching for a political consciousness should be the objective of every high school social studies teacher.

By corollary, it should not be controversial that social studies teachers focus on teaching for a stronger democracy. Furthermore, it is generally agreed that a majority of Canadians believe none of the alternatives to democracy are preferable political systems. Yet, if voting rates are any indication, it is arguable that democracy in Canada and elsewhere is on the wane. Low voter turnout is highest among younger voters (Statistics Canada, 2012; United States Census Bureau, 2010). ${ }^{3}$

There are flaws in Canada's democracy, of course (Orlowski, 2011). The first step in addressing these flaws is to make people aware of them, and high school social studies courses are an excellent venue to do this. Relying on teachers to teach for a stronger democracy is not a new idea. Several Canadian education theorists have made strong cases for such a role for social studies, civic studies, and history teachers (Christou, 2012; Hyslop-Margison \& Sears, 2008; Osborne, 1991, 1995; Von Heyking, 2006). The first educators to make exceptionally strong cases in this regard, however, were based in the United States. A quick look at a few of these more important philosophers of education will provide support for the case I make in this paper, namely, that the notion of teachers focusing on developing a political consciousness in their students is necessary in order to strengthen democracy. A political consciousness is integral to the continuance and improvement of our civil society.

John Dewey wrote extensively in the early part of the $20^{\text {th }}$ century on the potential of public education to strengthen democracy. In Democracy and Education, Dewey (1916) argues that public education offers the best hope to protect democracy against the possibility of despotic regimes. The mandate of the public school, according to Dewey, is to develop in each student critical thinking skills so that they will become informed and active citizens capable of solving complex social problems. In a later work, he stated: "The essential need is the improvement of the methods and conditions of debate, discussion and persuasion” (Dewey, 1927/1954, p. 207). Dewey’s “essential need” appears to be the basis about which social studies should be.

In the 1920s and 1930s, early education theorists such as Harold Rugg (1921) and George Counts (1932/1982) went a few steps further than Dewey in imagining a political role for teachers. They considered the biggest threat to democracy to be the concentration of economic, social, and political power in the United States. Their solution was for teachers to become leaders of social change (Stevens \& Wood, 1995). At the time that the United States was in the throes of the Great Depression, the school curriculum was the object of intense ideological 
struggles (Kliebard, 1986). Counts (1932/1982) demonstrated a critical left ideological perspective through a paper he delivered at the meeting of the Progressive Education Association entitled "Dare the schools build a new social order?"

By no means were these Americans educators major influences in Canadian social studies. I mention them because what they called for is very similar to what I am calling for here in Canada. The 1930s saw the rise of numerous protest movements that led to the New Deal in the United States (Smith, 2007), and the beginning of the social welfare state in Canada (Palmer, 1992). Many decades after Dewey (1916), Rugg (1921) and Counts (1932/1982) published their works, we find ourselves living in a historical moment with similar conditions in which large social movements arise on almost an annual basis. Occupy Wall Street, Idle No More and Quebec's Maple Spring came about to protest the extreme concentration of economic, social, and political power. These phenomena lead me to ask, "Dare we teach students to understand our social order?” If so, understanding neoliberalism is a major step in that direction.

\section{Neoliberalism: Laissez-Faire Economics Revisited?}

Everything that's happened in the past several years has gone to further empower and enrich the 1 per cent (or maybe the 5 per cent) at the expense of the rest of us. Look anywhere you want. What else does the universal demand for austerity programs mean? What else does the sudden concerted attack on public sector workers mean? What else does the intransigent line taken by multinational corporations against their unions mean? What else does the demand for "right-towork" laws mean? What else does the widespread attack on seniors' pensions mean? (Caplan, 2012, para. 2)

Neoliberalism can be a confusing term for students to comprehend. After all, progressive Americans and Canadians accept the basic tenets of liberalism in terms of individual rights and democracy. Neoliberalism, however, only refers to economic issues, not social issues. The "liberal" part of neoliberalism refers to its association with the economics of classical liberalism in opposition to the social liberal and state liberal orthodoxies of the late 19th and early 20th centuries. Adding to the confusion, both liberal and conservative governments in the U.S. and Canada have passed pro-corporate or neoliberal legislation while touting the free market discourse on the domestic and international fronts. Moreover, economic policy is difficult for people to understand because research has found that social class issues are an almost forgotten topic in high school social studies (Orlowski, 2011).

The key components of the neoliberal agenda are deregulation of the economy, tax cuts (especially for corporations and the wealthy), privatization of the commons, union busting, free markets, and free trade. ${ }^{4}$ The major theorists of neoliberalism are Friedrich von Hayek (1944) and, more recently, Milton Friedman (2002). As a veteran educator who has covered the Industrial Revolution to the 1930s many times in high school courses, I am struck by the similarities between past economic policy and contemporary neoliberal policy. Moreover, the bleak economic conditions for workers and their families from the past era are becoming the reality for much of the working classes today. This sense of déjà vu is understandable when one realizes that an economic model similar to neoliberalism had fallen out of favor with all Western nations during the Great Depression of the 1930s. This system used to be called laissez-faire economics. 
In high school social studies and history, students learn that income inequality, inhumane conditions for workers, and the lack of social safety nets were features of laissez-faire economics. Government-imposed regulations on industry were seen as impediments to financial profit for the capitalist class, and consequently, were unacceptable. Supporters of this doctrine in the 18th, 19th, and early 20th centuries preferred the invisible hand (Friedman, 2002) of the market to influence economic arrangements and were hostile to the state intervening in economic affairs, especially around regulation of industry. It is clear that similar thinking has permeated the thinking of many of the economic and political elites today.

One particularly effective discourse emanating out of corporate propagandists is the famous trickle-down theory that neoliberalism will help everyone no matter their social and economic standing - the deregulated economy will create a rising tide and all of the boats, big and small, will rise with it (Harvey, 2005). Another current powerful discourse in support of corporate tax cuts touts corporations as job creators. Research in Canada and the United States, however, demonstrates that large corporations do not use money from tax cuts to create more jobs (Stanford, 2011; Hungerford, 2012). Despite these findings, the job creator discourse is very powerful and works to gain the public's support for corporate tax cuts.

Under the banner of fiscal responsibility, neoliberal supporters in government, in the private sector, and in the media have been calling for opportunities to profit from privatizing the commons. They want funding cuts to public education in all countries receptive to neoliberalism (Hill, 2009), which more often than not are the English-speaking, Western nations. Charter schools continue to be in vogue in the United States. In Canada, entrepreneurial forces are pushing for the creation of a two-tiered healthcare system to replace its treasured universal public healthcare system and tacking on "Medical Services Plan" fees to erode the notion of a free, public service. Pension plans for public sector workers and the public are very much in peril (Kennedy \& Press, 2012). The reason given to the public is that it is no longer affordable to fund these public institutions and programs through taxes. Much of the public does not seem too concerned that these discourses are being trumpeted during a period in which the gap in income inequality between the rich and the poor is widening dramatically to proportions not seen since the 1930s (Frank, 2012). A type of shock doctrine is at work (Klein, 2007). Yet, the Occupy Wall Street and Idle No More movements indicate that a significant segment of society is beginning to assert some powerful connections among new coalitions.

Amidst countless stories in the U.S. of home foreclosures, job losses, and increased poverty in the summer of 2011 Occupy Wall Street arose to challenge the hegemonic discourses around the concentration of wealth: "We are the 99\%" became the slogan of this social movement, the first serious populist resistance to the neoliberal agenda in North America. In any European nation where austerity is being touted by the government, massive protests have filled the streets of urban centres. In the spring of 2012, moments after the Quebec government announced university tuition hikes, huge student protests appeared that were so relentless that they helped force a change in government (Giroux, 2012). And in the autumn of 2012, another social movement arose out of the Canadian prairies as Indigenous activists reached out to nonIndigenous Canadians in a show of solidarity to challenge corporate hegemony, environmental degradation, and the weakening of democracy (Dobbin, 2013). The Idle No More movement continues to attract support across the world as progressive and concerned citizens join with Indigenous peoples (Georgetti \& Barlow, 2013). 
All of these social movements are part of the common struggle against neoliberalism, the struggle to fight against the dismantling of civil society. The protests of the 1920s and 1930s led to the acceptance of Keynesian economics. In turn, and with active labour movements in Canada and the United States, the creation of the social welfare state became part of the body politic and the social fabric of both nations after the Second World War. A brief discussion of Keynesian economics will be helpful.

\section{From Laissez-Faire to State Interventionism to Neoliberalism}

According to the OECD (2011), all four Nordic countries-Denmark, Norway, Finland, and Sweden - place within the top nine nations in the world in terms of combating income inequality. All four nations are social democratic, capitalist countries. Social democratic political parties are established in almost every Western nation. The one Western nation without a social democratic party is the United States, where rabid conservative McCarthyism of the late 1940s and early 1950s inhibited its development. A majority of citizens across Western nations, including the United States, experienced three decades of an increased standard of living after the Second World War, mostly because of interventionist government economic policy and the resultant social welfare state (Krugman, 2009; Laxer, 1999). Canadian students should understand the political journey that led Western nations to these progressive economic values.

In the 1920s, British macroeconomist John Maynard Keynes understood that the selfcorrecting aspect of capitalism, also known as the hidden hand of the market, was a myth. This led him to advocate for the unthinkable: state intervention in the economy by pumping money into the system. The idea was to get the idle factories up and running with the labour of the formerly unemployed, now the newly employed. ${ }^{5}$ Keynes demanded that the economy serve the interests of the people, not the other way around as it was with classical economics. McQuaig (1998) states, "Keynes showed that through government, we can exert enormous control over our economy and therefore over our lives" (p. 212). In other words, an informed public could elect politicians who had the best interests of the mass of people in mind, not simply the best interests of the elites. In Canada from the mid-1940s until the late 1970s, the acceptance of Keynesian economics provided the basis for state interventionism, a strong social welfare state, and an expanding economy throughout the West (Laxer, 1999).

Why have Keynes' economic theories fallen out of favour in contemporary Canada and, indeed, much of the world? A major factor is the recent political convergence of neoliberalism's corporate agenda with the resurgence of American social conservatism. This resurgence began with Barry Goldwater's unsuccessful campaign for the American presidency in 1964. But the movement really began to spread in the 1970s, and with the election of Ronald Reagan in 1980, neoliberalism was in the White House (Krugman, 2009). Frank (2004) explains how corporate executives and politicians, backed by corporate media pundits, managed to channel working class anger over social issues, such as same-sex marriage, into support for their corporate agenda. Frank (2004) calls this anger the “Great Backlash”:

The Great Backlash has made the laissez faire revival possible, but this does not mean that it speaks to us in the manner of the capitalists of old, invoking the divine right of money or demanding that the lowly learn their place in the great chain of being. On the contrary, the backlash imagines itself as a foe of the elite, as the voice of the unfairly persecuted, as a righteous protest of the people on history's receiving end. That its champions today control 
all three branches of government matters not a whit. That its greatest beneficiaries are the wealthiest people on the planet does not give it pause. (p. 6)

This, then, has been the neoliberal strategy: convince working class Americans and Canadians to support politicians who pay some attention to traditional conservative values while deregulating the financial industry and privatizing as much of the commons as possible. The creation of the Tea Party and its current role in the Republican Party has been the crowning achievement of this movement. The Reform Party that appeared in the prairies in the early 1990s is the Canadian counterpart, and an argument can be made that this movement formed the federal Canadian government with the election of Stephen Harper's Conservatives in $2006 .{ }^{6}$ The discussion now turns to the victories for common middle and working class Canadians and Americans brought about by an informed and active public in both countries.

\section{Progressive Economics in Canada's Post World War II Period}

For the most part, the creation of the social welfare state in Canada has been enacted by liberal governments at the federal level, and by socialist or social democratic governments at the provincial level (Lam 2011; Laxer, 1999; Ricci, 2009; Whitehorn, 1992). At the federal level, for example, Liberal Prime Ministers such as Lester Pearson and Pierre Trudeau supported legislation that strengthened collective bargaining rights and implemented public healthcare across the nation (Ricci, 2009). Since 1993, however, the performance of governments with the Liberal moniker in Canada is replete with examples imbued with neoliberal orthodoxy (Albo, 2007; Barlow \& Campbell, 1995). There has yet to be a federal social democratic government in Canada, so the discussion will first turn to what is meant by social democracy and some of the progressive legislation enacted in its name.

I recognize that there are multiple meanings of the term social democracy. Indeed, many use the term interchangeably with democratic socialism (Whitehorn, 1992). For the purposes of this discussion, proponents of social democracy assert that capitalism can only work if it is effectively regulated on behalf of the public good. In this way, social democracy is in opposition to the neoliberal doctrine of the infallibility of "the invisible hand of the market" (Friedman, 2002).

Social democracy seeks to further extend and protect individual rights, political democracy (including the equal right to vote), and social as well as economic democracy (including the equal right for all to an education, healthcare, employment, safe working conditions, and pensions). It is an inclusive political ideology in that one of its basic tenets is to promote minority rights, a position it shares on the social spectrum with liberalism. On economic issues, however, social democracy differs greatly from liberalism in that it strongly supports the social welfare state through progressive taxation and the selective application of government monopolies.

A major objective of social democracy is to protect the commons, especially public education, and, in Canada, public healthcare, as well. Therefore, social democracy is a political ideology that runs counter to the aims of neoliberalism and goes beyond the social liberalism associated with the more progressive elements of the Democratic Party in the U.S. or Canada's Liberal Party. Social liberals are considerably less prone toward public ownership of industry. Although social liberals are committed to equal economic opportunity, they are less inclined to grapple with the wealth gap than social democrats. There is much evidence, however, that 
supports curtailing the extreme wealth imbalance in a nation (Wilkinson \& Pickett, 2010). In fact, the degree of inequality provides the major influence on the psychological well-being of a nation's citizens. Bearing the Scandinavian countries in mind, social democracy is the ideology best suited to this dual task of wealth distribution and collective psychological wellness.

Social democratic governments have been elected in several Canadian provinces. In 1961, the New Democratic Party (NDP) evolved out of the more socialist-oriented Cooperative Commonwealth Federation (CCF), with closer ties to organized labor (Laxer, 1999; Whitehorn, 1992). In Saskatchewan, the CCF/NDP passed progressive legislation for the common good, much of it the first of its kind in North America. For example, under the leadership of Premier Tommy Douglas, some of the CCF's more successful laws included the Saskatchewan Bill of Rights in 1947, the Saskatchewan Arts Board in 1948, and perhaps the crowning achievement, a universal public healthcare system in 1962 (Lam, 2011; Whitehorn, 1992).

NDP governments have also been elected on several occasions in British Columbia and Manitoba, and once in both Ontario and Nova Scotia. As well, the Parti Quebecois enacted several social democratic pieces of legislation in Quebec, especially during the 1970s and early 1980s. Wherever social democratic governments have appeared in Canada, financial support for the social welfare state increased, as did legislation in support of worker's rights to collectively bargain and to better working conditions (Whitehorn, 1992). For example, in British Columbia, the NDP has enacted anti-scab legislation that effectively blocks employers from hiring replacement workers during work stoppages from lockouts or strikes.

In Canada, social democrats are perceived as the defenders of social programs, especially universal healthcare. Further, in terms of funding, public education fares much better with a social democratic government. Other common NDP initiatives include public auto insurance, a commitment to negotiating land treaties with First Nations people, regulating industry (including banks), and the protection of prime agricultural land from urban development. Neoliberal governments are wont to privatize aspects of the commons, however, such as the important potash industry in Saskatchewan, and to allow the introduction of private healthcare into the system. It should be noted, however, that the Canadian federal Liberal governments of the 1990s broke away from neoliberal doctrine by refusing to deregulate the financial industry, despite great pressure from the banks to do so (Laxer, 1999; McQuaig, 1998).

It is worth noting that social democratic reforms are more popular in practice than in the rhetoric of politics (Murphy, 2009). This may be one of the prime examples of a psychological disconnect between political discourse and popular political programs. The discourses around low taxes and privatization are adhered to even by those who value and sometimes depend on the social safety net (Orlowski, 2011). A difficulty in overcoming this false political consciousness arises because to do so opens one to the charge of engaging in class warfare.

\section{Is This What Class Warfare Looks Like?}

For several decades, the economic elites in Canada and the United States have dismissed any notion that they have been implicated in any kind of class warfare. Indeed, the economic elites and particular media pundits who support them (and in some cases work for them) will use the term "class war" whenever they detect "public contempt for investment bankers" (Frank, 2012, p. 37). Particularly in the U.S., it seems that simply talking about the wealth gap or poverty is enough for the Right to call out loudly, "This is class warfare." These same pundits do not decry 
the economic policies such as tax cuts that create the unequal distribution of wealth. Yet, despite much of the corporate media's attempts at obfuscation, when one considers the dramatically increasing gaps in wealth, there can be little doubt that neoliberalism is, indeed, "a project aimed at the restoration of class power" (Anijar \& Gabbard, 2009, pp. 45-46). Harvey (2005) states, "If it looks like class struggle and acts like class war then we have to name it unashamedly for what it is” (p. 202). There has been a class war enacted by the economic and political elites for over 30 years (Laxer, 1998) - first, the victims were working class families, and in recent years, the middle classes have been targeted (Monsebraaten, 2011; Freeland, 2012; Yalnizyan, 2011).

A brief look at the havoc wrought by neoliberalism in the United States will make the point more clear. During the 1980s, Reagan Republicans began touting deregulation as a way to allow the economy to flourish (Frank, 2004; Laxer, 1999; McQuaig, 1998). This was instrumental for the neoliberal agenda to gain traction in the American economy. Today, it is clear that the savings and loans scandal of the 1980s and the sub-prime mortgage crisis of 200708 are directly related to the deregulation of the financial industry (Frank, 2012). Another centerpiece of neoliberalism that has brought economic chaos to the U.S. budget involves taxation policy. Americans are currently witnessing a battle between forces in favour of ending the tax cuts for the wealthy that were brought in under the George W. Bush administration and neoliberal forces pushing for even more tax cuts, especially for the corporate sector.

Despite commonly held views, it is not much better in Canada. According to the Conference Board of Canada, the gap between the wealthiest Canadians and everyone else has also greatly increased over the past two decades (Caplan, 2012; Cooper, 2013; Monsebraaten, 2011). In both countries, powerful forces are attempting to supplant the values of progressive liberalism and social democracy with neoliberal values. The only possible result from this is greater wealth inequality and the concomitant reduction of political influence of the working and middle classes.

Neoliberalism began to gain traction in the U.S. during the Reagan presidency of the 1980s. According to the Organization for Economic Cooperation \& Development (OECD) 2011 Report entitled Divided We Stand: Why Inequality Keeps Rising, since the 1980s there is a clear link between a rising wealth gap and the onset of neoliberal policies in most OECD countries that implemented them. Moreover, in 2009, nearly 44 million Americans were living in poverty, which was four million more than the previous year (Herbert, 2011). The growing inequality trend is similar in Canada. The Conference Board of Canada (as cited by Monsebraaten, 2011) states, that between 1976 and 2009 the earnings gap between the lowest 20\% and the top 20\% of earners almost doubled. On a related issue, child poverty in both countries is worsening. UNICEF reports that Canada ranks 24 out of 35 industrialized nations with a child poverty rate of $13.3 \% .^{7}$ The U.S. situation is much worse: $23 \%$ of American children live in poverty, and only Romania has a worse rate (Monsebraaten, 2012).

A false political consciousness is leading many working- and middle-class people to support neoliberal policies for deregulation, privatization of the commons, union busting, and tax cuts for wealthy entities (Orlowski, 2011; Frank, 2012). Neoliberalism is most often promoted in the corporate media with discourses that resonate with people hoping to improve their economic well-being. Yet, as the massive numbers of home foreclosures and personal bankruptcies in the United States demonstrate, ${ }^{8}$ not everyone's standard of living improves. Less well-known are the incendiary policies that go along with deregulation and privatization. These include roles for the 
state to protect the quality of money itself, to ensure that military, police, and legal infrastructures exist to guarantee the proper functioning of markets (by force, if necessary), and to secure private property rights and a weakening of bankruptcy laws. Lastly, neoliberalism emphasizes that the role of the state must include creating markets in areas such as education, healthcare, social security, and environmental pollution (Harvey, 2005). If citizens understood this, it is unlikely that the majority would support the neoliberal project.

Further, citizens are likely unaware that work stoppages are often at the whim of the employers. Look at recent American statistics: "The number of strikes has declined to just onesixth the annual level of two decades ago....[1]ockouts, on the other hand, have grown to represent a record percentage of the nation's work stoppages” (Greenhouse, 2012). The American working class has clear evidence that neoliberal politicians and CEOs have been engaging in class warfare. The day after Michigan passed a "so-called right-to-work law aimed at weakening unions in that state," the Canadian federal government passed Bill C-377 in the House of Commons (Walkom, 2012). This new law is "designed to tie the unions up in red tape and-its backers hope-embarrass labour's leadership” (Walkom, 2012). If this was not enough evidence of the Conservative government's disdain for unions and the working classes of Canada, there have been several examples of using back-to-work legislation rather than allowing the collective bargaining process to move toward negotiated contracts (Baluja, 2012).

In sum, since the 1980s, citizens in Canada have been inundated with a set of discourses and legislation designed to further the economic power of the elites. At the same time, poverty levels in Canada have reached levels not seen since the 1930s. These discourses have evolved into an extremely powerful discursive formation that comprises the underpinnings of neoliberalism: corporate tax cuts, deregulation, privatization, free markets, and union busting. Conservatism and the more progressive liberalism have been unable to protect civil society and democracy from the ravages of neoliberalism. Neoliberalism provides the basis for a new class war, one that is attempting to replace the Fordist arrangement between capital and labor, and curtail or end the influence of Keynesian economics. Recent social movements such as Occupy Wall Street and Idle No More indicate that significant segments of society are emerging to challenge this class war.

Our dominant political discourses need not be these. It should not be surprising to learn that corporate media have corporate interests. By corollary, corporate media is clearly on the side of corporate privilege or neoliberalism. Social studies and civic studies teachers should be on the side of civil society.

\section{Teaching for Civil Society}

An understanding of how the control of cultural institutions enhances the power of particular classes to control others can provide needed insight into the way the distribution of culture is related to the presence or absence of power in social groups. (Apple, 2004, p. 14)

Informed citizens are the basis of any democratic society. (B.C. Ministry of Education, 2005, p. 12)

Throughout my entire teaching career, I have been taken aback by how many students say that they cannot understand the news when it focuses on politics. Indeed, I am also astonished by 
how many adults say the same thing. This indicates a major reason for the perceived sense of powerlessness. When it comes to understanding politics, a significant portion of the population is unable to do so - they are politically uninformed and unaware of how economic power operates. This is likely a reason why neoliberalism has been able to replace the Keynesian model without very much effective resistance.

In Critical Democracy and Education, Kincheloe (1999) suggests an outline based on critical pedagogy that would lead students to become politically conscious: "The curriculum becomes a dynamic of negotiation where students and teachers examine the forces that have shaped them and the society in which they live" (p. 73). Kincheloe calls for teachers to develop an enacted curriculum that encourages self-reflection and lifts the hegemonic veil away from the hidden power structures. Bearing this important point in mind, the first concept I teach in every social studies course, at both the high school and the university level, is ideology critique.

\section{Ideology Critique}

In order to help students understand the major political ideologies, I first categorize myriad issues as either social or economic (See Appendix A). For example, on the social spectrum, minority rights are on the left side, while the conservative pro-life and pro-death penalty positions are on the right. On the economic spectrum, tax cuts are on the right side, while publicly funded social welfare programs are on the left. In the current American context, the conservative Republicans are on the right side of both spectrums, while the liberal Democrats are on the left of the social spectrum and the right of the economic spectrum. Clearly, both major American parties serve corporate interests rather than the economic interests of the common individual. In Canada, the Conservative Party and the Liberal Party are positioned slightly left of where their American ideological counterparts are; yet, the social democratic NDP is on the left side of both the social and economic spectrum. By the end of every course I teach, either in the high school classroom or in teacher education programs, the student has at least a basic understanding of where the political parties stand on the various social and economic issues. The next pedagogical step is to emphasize the role of the corporate media as a hegemonic device.

\section{The Case for Critical Media Literacy}

It is imperative that American and Canadian citizens understand the role of the corporate media in influencing the political ideologies of the public. As Herman and Chomsky (1988) point out, the major role of the corporate media is to manufacture consent in order to shape the collective consciousness in ways that further the interests of the elite. This is accomplished not only by how issues are covered, but also by which issues receive coverage. The meaningfulness of media analysis and its relationship to an informed citizenry should be evident to all social studies teachers. The rise of social media has broadened this challenge.

Media literacy can take two basic forms: one looks at the pleasures within a capitalist society and how certain groups are represented, and the other looks at politics and the media's role in shaping public opinion. This second approach is the one I focus on, especially around neoliberalism. For example, it enables the teacher to illuminate the effects of various hegemonic discourses used by the media that portray the poor as lazy, or the public sector workers as entitled, while ignoring the growing wealth gap. 
There are myriad examples of the media ignoring certain events and policies if there is a perceived threat that the public might turn against the ruling classes. For example, over the past few years, there has been a concerted effort in many Western nations to weaken or eliminate altogether pension plans for many workers. In our experience, the vast majority of students are unaware of the similarities of the American and Canadian attacks on a hard-earned and vital benefit for the working- and middle-classes. These examples demonstrate media omission as a hegemonic strategy.

Another hegemonic strategy involves understanding the power of language. We are living in a time in which bias, or "spin," has been hyperbolized to extreme proportions. As an example of current spin, the tendency to limit worker's collective bargaining rights is not called union busting; rather, the mainstream media and neoliberal politicians refer to it as labor flexibility. Lowering the minimum wage is called Right to Work legislation.

The Orwellian spin strategy has recently been put to good use in Canada. In 2011, the Conservative government passed a bill called "Marketing Freedom for Grain Farmers Act" that effectively ended the grain price controls put in place in 1935 through the Canadian Wheat Board. This creates a clear disadvantage for the small wheat and barley farmers. Similarly, "The Safe Streets and Community Act” passed in 2012 includes the dual function of building more prisons while increasing penalties for marijuana possession. Does the use of this strategy mean the government acknowledges a lack of support for these laws? It is difficult to know; however, what is certain is that students should be made aware of such bills so that they can be critically debated and understood, which is another important role for teachers of social and civic studies.

A counterhegemonic strategy that I have found successful in the high school classroom involves students accessing and assessing media sources. Students demonstrate the degree to which they have become adept at explaining cultural struggles in ideological terms in their current events presentations. Each chooses an article from one of the mainstream newspapers or from an alternative news source (such as Alternet.org or TheTyee.ca), most of which come from the Internet. The chosen article must address a cultural issue, namely, race, class, gender, sexuality, or war. Each student provides a one-page written analysis to address issues of bias to show which groups benefit and which ones lose from the given ideological perspective. They must offer their thoughts about who was quoted and why, and which affected groups were excluded. Each student must also present his or her findings to the class with a 4-5 minute presentation.

Some students choose only articles from mainstream sources, while others willingly, even enthusiastically search the alternative sources. This has worked well, pedagogically speaking, because students often choose articles on similar topics - the 2004 American election and the Iraq war were two favourites - and the ideologies emanating from mainstream and alternative sources are not difficult to discern. For a more recent example, students compared how Fox News and similar media outlets differed in their coverage of the Tea Party and Occupy movements. Media bias is quite apparent with such pedagogy. These assignments offer students a framework in which to critique the media in terms of the ideological influences of journalists, and in the process they understand how most of the mainstream media often reflects the views of powerful interests. Indeed, when students challenge the language and the assumptions that many journalists use, they see how the hegemonic function of the media works in the interests of large 
corporations and other privileged groups. Some are able to see past the effects of a false consciousness.

In recent years, I have had students look specifically for neoliberal policy being promoted or challenged by some politicians or business representatives in the corporate media. They are to look for news articles discussing deregulation, privatizing the commons, unions, or tax cuts and to analyze the language used. The goal of this exercise is two-fold: first, to demonstrate to students the proliferation of neoliberal policies, and second, to help them comprehend how language leads many people to believe that work stoppages are most often a result of striking workers rather than lockouts.

Students come to understand that the dominant discourses used in corporate media support the interests of elites over the common good; indeed, they support profits over broad, societal interests. The dominant neoliberal discourses in the corporate media for the past 25 years - tax cuts, deregulation, debt reduction, cuts to social programs, and free global markets - have been the building blocks for the resurgence in economic and political power for the elites in North America. Countless working class people, as well as much of the middle class, have had their lives significantly disrupted by this series of economic policy shifts supported by the corporate media.

\section{Re-framing Discourse}

I have been experimenting with a more sophisticated kind of media literacy, one based on reframing political discourse from different ideological perspectives (Lakoff, 2004). The basic theory behind reframing is to address the observation that people who are strongly influenced by any particular ideology find it difficult to listen to facts that might shake their beliefs. The facts do not seem to matter; the intended listener most often remains entrenched in their belief. Rather than become frustrated, progressive ideologues need to use positive discourses on policy that rely on progressive values and language. In other words, rather than using the familiar frames of the conservatives, progressives use ones based on social democratic values.

One example from the teacher education program may help to explain the value in reframing. For the neoliberal agenda to continue, significant numbers of poor and working class people must vote against their own best interests_or not vote at all. The necessary reframing efforts on the part of neoliberal conservatives are successful because a commonly held belief today is that conservative ideas are populist, while liberal or progressive ideas are elitist (Frank, 2012). To counter this, I use a pedagogical strategy that has the preservice teachers reframe neoliberal arguments using progressive values. For example, neoliberal media pundits often attack any notion of increasing the mandated minimum wage by calling it antithetical to business success. Instead of defending an increase in the minimum wage, one student reframed the debate and focused on the value of "prosperity for all who work hard." This is an idea that people across the ideological spectrum could support.

Another student produced a defense of taxes not by buying into the neoliberal frames of "tax relief" or "taxes as burden," but by using a social democratic frame — “fair tax reform”- which indicates that wealthy people should pay their fair share and that taxes are an investment for the future prosperity of everyone's children. Of course, media access and media compliance are important obstacles to these progressive frames becoming commonly accepted. 
For now, however, if teachers can comprehend corporate media neoliberal discourses, they should be better able to help their students deconstruct the bias that they are experiencing. After all, a major objective of critical media literacy is to help students to interpret the news rather than simply absorb it without reflection. This is a crucial pedagogical strategy: to develop a political consciousness in which individuals understand and defend their best interests.

\section{Some Final Reflections}

In both the United States and Canada, federal economic policy continues to favour the affluent at the expense of everyone else. A false political consciousness appears to have been constructed by the intricate intersection of multiple media discourses and political party rhetoric. The result is that many people who would benefit from social welfare programs are either apathetic or even supportive of their dismantling - they vote for parties touting tax cuts. Clearly, democracy is weakened under these conditions. I have found that an approach employing ideology critique, critical media literacy, and reframing of neoliberal discourses with progressive ones has been most effective when working with high school students and preservice teachers. Deconstructing hegemony is the crucial component of this critical pedagogy.

I have no idea how many former students become active citizens in the struggles to strengthen democracy and maintain civil society. Yet, I am certain that the vast majority of them are much more informed on political issues important to them. Most leave with a more sophisticated political consciousness, a critical consciousness that addresses the forces that influence their lives. Neoliberalism is one of the major forces they can recognize. Most are able to see it as an anti-democratic force that threatens civil society more than any other economic philosophy since the Second World War.

Although it may seem like neoliberalism has a strong grip on the political economic landscape, there is both hope and possibility. Because we live in democracies, social movements can emerge and push back. Regressive neoliberal legislation can be repealed and new social and economic policies that transcend simple market politics can be implemented. Teachers have an important role in deconstructing poverty-causing neoliberal discourses, especially tax cuts, union busting, privatizing the commons, and deregulation. Social democratic and progressive liberal values-progressive tax reform, support for workers, strengthening social welfare such as pension plans, and regulating industry — are the antithesis of neoliberalism. The OECD (2011) report concludes that countries adopting neoliberalism experience increased poverty. The report also states that nations with a history of social democratic governments, most notably in Scandinavia, have been better able to withstand neoliberal forces so that poverty is not as prevalent. Teachers of social studies, civic studies, and history have an important role in making human dignity a universal value. It really is about maintaining civil society or even building a stronger one. 


\section{References}

Albo, G. (2007, April). Neoliberalism and Canada’s ruling class. Monthly Review. Retrieved from http://mrzine.monthlyreview.org/2007/albo070407.html

Anijar, K., \& Gabbard, D. (2009). Vouchers, charters, educational management organizations, and the money behind them. In D. Hill (Ed.), The rich world and the impoverishment of education: Diminishing democracy, equity and workers' rights (pp. 21-50). New York, NY: Routledge.

Apple, M. (2004). Ideology and curriculum, (3rd ed.). New York, NY: Routledge-Falmer.

Baluja, T. (2012, March 12). Citing economic impact, Lisa Raitt orders Air Canada back to work. Globe \& Mail. Retrieved from http://www.theglobeandmail.com/news/politics/ottawa-notebook/citing-economic-impactlisa-raitt-orders-air-canada-back-to-work/article553244/

Barlow, M., \& Campbell, B. (1995). Straight through the heart: How the Liberals abandoned the Just Society and what Canadians can do about it. Toronto, ON: HarperCollins Publishers, Ltd.

B.C. Ministry of Education, Skills, and Training. (2005). Civic Studies 11: Integrated resource package 2005. Victoria, BC: Queen’s Printer for British Columbia.

Caplan, G. (2012, February 24). Don’t tell us it's not class war. The Globe \& Mail. Retrieved from http://www.theglobeandmail.com/news/politics/second-reading/gerald-caplan/donttell-us-its-not-a-class-war/article2349194/

Christou, T. M. (2012). Progressive education: Revisioning and reframing Ontario's public schools, 1919-1942. Toronto, ON: University of Toronto Press.

Cooper, J. (2013, September 9). Income gap issues worsen. StarPhoenix. Retrieved from http://www.thestarphoenix.com/business/Income+issues+worsen/8886312/story.html

Counts, G. (1982). Dare the school build a new social order? (1932) Reprinted as "Dare progressive education be progressive?” Progressive Education, 9, 257-263.

Dewey, J. (1916). Democracy and education. New York, NY: MacMillan.

Dewey, J. (1927/1954). The public and its problems. New York, NY: Holt.

Dobbin, M. (2013, January 14). The power of Idle No More’s resurgent radicalism. The Tyee. Retrieved from http://m.thetyee.ca/Opinion/2013/01/14/Idle-No-More-Radicalism/

Frank, T. (2004). What's the matter with Kansas? New York, NY: Henry Holt \& Co.

Frank, T. (2012). Pity the billionaire: The hard-times swindle and the unlikely comeback of the right. New York, NY: Henry Holt \& Co.

Freeland, C. (2012, Jan/Feb). The rise of the new global elite. Atlantic Magazine. Retrieved from http://www.theatlantic.com/magazine/archive/2011/01/the-rise-of-the-new-globalelite/8343/ 
Friedman, M. (2002). Capitalism and freedom (2nd ed.). Chicago, IL: University of Chicago Press.

Georgetti, K., \& Barlow, M. (2013, January 11). Why Idle No More has resonated with Canadians. Rabble.ca. Retrieved from http://rabble.ca/news/2013/01/importance-idle-nomore-and-power-collective-action

Giroux, H. (2012, August 28). Days of rage: The Quebec student protest movement and the new social awakening. Truthout. Retrieved from http://truth-out.org/opinion/item/11040-thequebec-student-protest-movement-and-the-power-of-the-radical-imagination

Greenhouse, S. (2012, January 22). More lockouts as companies battle unions. The New York Times. Retrieved from http://www.nytimes.com/2012/01/23/business/lockouts-once-rareput-workers-on-the-defensive.html?pagewanted=all

Harvey, D. (2005). A brief history of neoliberalism. Oxford, UK: Oxford University Press.

Hayek, F. A. (1944). The road to serfdom. Chicago, IL: University of Chicago Press.

Herbert, B. (2011, January 7). Misery with plenty of company. New York Times. Retrieved from http://www.nytimes.com/2011/01/08/opinion/08herbert.html

Herman, E., \& Chomsky, N. (1988). Manufacturing consent: The political economy of the mass media. New York, NY: Pantheon Books.

Hill, D. (Ed.). (2009). The rich world and the impoverishment of education: Diminishing democracy, equity and workers' rights. New York, NY: Routledge.

Hungerford, T. (2012, September 14). Taxes and the economy: An economic analysis of the top tax rates since 1945. Congressional Research Service for Congress. Retrieved from http://graphics8.nytimes.com/news/business/0915taxesandeconomy.pdf

Hurtig, M. (1999). Pay the rent or feed the kids: The tragedy and disgrace of poverty in Canada. Toronto, ON: McClelland \& Stewart, Inc.

Hyslop-Margison, E., \& Sears, A. (2008). The neo-liberal assault on democratic learning. UCFV Research, 2(1), 28-38.

Kennedy, M., \& Press, J. (2012, January 26). “Major transformations” coming to Canada’s pension plan, Harper tells Davos. National Post. Retrieved from http://news.nationalpost.com/2012/01/26/major-changes-coming-to-canadas-pensionsystem-harper-says-in-davos-speech/

Kincheloe, J. (1999). “Critical democracy and education.” In J. G. Henderson \& K. R. Kesson (Eds.), Understanding democratic curriculum leadership (pp. 70-83). New York, NY: Teachers College Press.

Klein, N. (2007). The shock doctrine: The rise of disaster capitalism. Toronto, ON: Alfred A. Knopf Canada.

Kliebard, H. (1986). The struggle for the American curriculum: 1893-1958. New York, NY: Routledge \& Kegan Paul. 
Krugman, P. (2009). The return of depression economics and the crisis of 2008. New York, NY: W. W. Norton \& Company, Inc.

Lakoff, G. (2004). Don't think of an elephant! Know your values and frame the debate. White River Junction, VT: Chelsea Green Publishing.

Lam, V. (2011). Tommy Douglas. Toronto, ON: Penguin Group (Canada).

Laxer, J. (1999). The undeclared war: Class conflict in the age of cyber capitalism. Toronto, ON: Penguin Books.

McQuaig, L. (1998). The cult of impotence: Selling the myth of powerlessnesss in the global economy. Toronto, ON: The Penguin Group.

Monsebraaten, L. (2011, July 13). Canada’s income gap growing. Toronto Star. Retrieved from http://www.thestar.com/news/article/1024027--canada-s-income-gap-growing

Monsebraaten, L. (2012, May 29). Canada lags on fighting child poverty, report finds, Toronto Star. Retrieved from http://www.thestar.com/news/canada/article/1202030--canada-lagson-fighting-child-poverty-report-finds?bn=1

Murphy, J. M. (2009, Summer). Political economy and rhetorical matter. Rhetoric \& Public Affairs, 12, 303-315.

OECD. (2011). Divided we stand: Why inequality keeps rising. Paris, France: Organization for Economic Co-operation and Development. Retrieved from http://www.oecd.org/social/soc/dividedwestandwhyinequalitykeepsrising.htm

Orlowski, P. (2011). Teaching about hegemony: Race, class \& democracy in the $21^{\text {st }}$ century. New York, NY: Springer.

Osborne, K. (1991). Teaching for democratic citizenship. Montreal, QC: Our Schools Our Selves Education Foundation.

Osborne, K. (1995). In defense of history: Teaching the past and the meaning of democratic citizenship. Toronto, ON: Our Schools Our Selves Press.

Palmer, B. (1992). Working-class experience: Rethinking the history of Canadian labour, 18001991. Toronto, ON: McClelland \& Stewart.

Ricci, N. (2009). Pierre Elliott Trudeau. Toronto, ON: Penguin Canada.

Rugg, H. O. (1921). Reconstructing the curriculum: An open letter to Professor Henry Johnson commenting on Committee Procedure as illustrated by the Report of the Joint Committee on History and Education for Citizenship. Historical Outlook, 12, 184-189. Reprinted in W. C. Parker (Ed.) (1996). Educating the democratic mind. Albany, NY: State University of New York Press.

Smith, J. E. (2007). FDR. New York, NY: Random House, Inc.

Stanford, J. (2011). Having their cake and eating it too: Business profits, taxes, and investment in Canada-1961 through 2010. Ottawa, ON: Canadian Centre for Policy Alternatives. 
Statistics Canada. (2012). Factors associated with voting. Ottawa, ON: Statistics Canada. Retrieved from http://www.statcan.gc.ca/pub/75-001-x/2012001/article/11629-eng.htm\#a1

Stevens, E., \& Wood, G. (1995). Justice, ideology, and education: An introduction to the social foundations of education (1st ed.). Toronto, ON: McGraw-Hill.

United States Census Bureau. (2010). Voting and registration in the election of November 2010 - Detailed tables. Washington, D.C.: U.S. Census Bureau. Retrieved from http://www.census.gov/hhes/www/socdemo/voting/publications/p20/2010/tables.html

Von Heyking, A. (2006). Creating citizens: History and identity in Alberta's schools, 1905 to 1980. Calgary, AB: University of Calgary Press.

Walkom, T. (2012, December 12). It's not the political right that's killing unions. Toronto Star. Retrieved from http://www.thestar.com/news/canada/2012/12/12/walkom_its_not_the_political_right_that s_killing_unions.html

Whitehorn, A. (1992). Canadian socialism: Essays on The CCF-NDP. Toronto, ON: Oxford.

Wilkinson, R., \& Pickett, K. (2010). The spirit level: Why equality is better for everyone. London, ON: Penguin Books.

Yalnizyan, A. (2011, April 7). Middle class in decline is the electoral elephant in the room. The Globe \& Mail. Retrieved from http://www.theglobeandmail.com/report-onbusiness/economy/economy-lab/the-economists/middle-class-in-decline-is-the-electoralelephant-in-the-room/article1974539/

\section{Endnotes}

${ }^{1}$ The K-12 school system in Canada is regulated at the provincial level. Some provinces such as Ontario and Quebec do not have high school social studies. A few provinces, including Ontario, have high school civics studies courses. Ontario also has a Grade 12 History course called “Canada: History, Identity \& Culture” that addresses similar issues as senior level social studies courses do in other provinces. The arguments and suggestions made in this paper are also relevant to these types of courses in the high school social sciences.

${ }^{2}$ There will be frequent references to what is happening in the United States in terms of the neoliberal agenda. This is because what occurs in that country often finds adherents attempting to bring similar policies into Canada.

${ }^{3}$ Although young adults are less inclined to vote, they are much more likely to have their voices heard by participating in actions of non-violent civil disobedience and mass protests such as Occupy Wall Street and Idle No More.

${ }^{4}$ Occupy Wall Street was primarily focused on the growing wealth gap in the United States (and Canada) and regressive tax policy. Idle No More initially arose as a reaction against the Canadian government's deregulation of environmental policy. Regressive tax policy and deregulation of industry are hallmarks of neoliberalism (Orlowski, 2011). 
${ }^{5}$ The massive bailouts of 2007 and 2008 in the United States were not a return to Keynesian economics — the tax dollars went straight to the entities that had caused the economic crisis, namely, the financial institutions.

${ }^{6}$ This is not to suggest that the Harper Conservatives were the first to bring the neoliberal agenda to Canadian economic policy. The Mulroney Progressive Conservatives and the Chretien Liberals began replacing Keynesian economic policy with neoliberalism (Laxer, 1998; McQuaig, 1998) prior to Harper's corporate Conservatism.

${ }^{7}$ In 1989, an all-party commitment was made in the House of Commons to eradicate Child Poverty in Canada by 2000 (Hurtig, 1999; Laxer, 1999). Since 1989, however, child poverty has greatly increased under both Liberal and Conservative governments.

${ }^{8}$ Alan Greenspan, a self-proclaimed devotee of Ayn Rand, deregulated the financial institutions over his 19-year reign from 1987-2006 as the chair of the U.S. Federal Reserve (Frank, 2012). Canadian banks were not deregulated to this extent. 


\section{Appendix A}

An effective way for students to understand political ideology is to consider all issues as either economic or social. Economic issues are those that represent significant amounts of money, while social issues do not. For example, capital punishment is a social issue while tax reform is an economic issue. The case can be made that some issues are both social and economichealthcare is a case in point-yet, to save on getting mired in semantics, the basic economic/social distinction is useful.

With political ideologies and political issues divided into the economic and the social, students are able to make headway around why certain media are called left wing by some, and the very same media outlets are called right wing or right leaning by others. For example, during the past few federal elections in Canada, leaders of the federal Liberal Party appeal to social democrats (that is, supporters of the New Democratic Party) as having values that have appeared out of the same concerns for justice, and that their vote should switch to the Liberals. The truth of the matter is that on social issues, they are correct. On economic issues, however, the two parties diverge significantly - the Liberals are to the right of center, closer to where the Conservative Party are positioned, while the NDP are to the left of center. (Note: The point about the Liberal Party being left wing on social issues and right wing on economic issues is rarely mentioned in the corporate media. The same point is true about media coverage of the U.S. Democrats.)

\section{Figure 1: Left and Right on the Social and Economic Spectra}

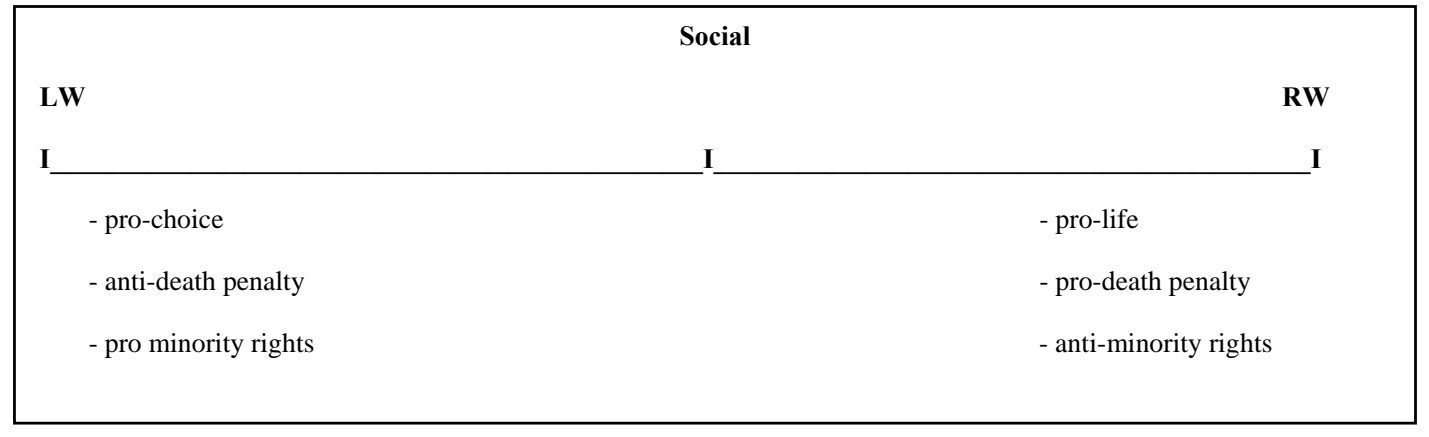

\begin{tabular}{|l|l|}
\hline LW & Economic \\
\hline - strong social welfare state & - anti social welfare state \\
- pro publicly funded universal healthcare & - for profit healthcare \\
- pro-union & - anti-union \\
- wealthy pay tax at a higher rate & - tax cuts for all \\
\end{tabular}




\section{$\underline{\text { Assignment }}$}

1. Research the platforms of the following American political parties:

- The Republican Party

- The Democratic Party

- $\quad$ The American Green Party

2. Research the platforms of the following Canadian political parties:

- The Liberal Party

- $\quad$ The Conservative Party

- $\quad$ The New Democratic Party

- The Bloc Quebecois

- The Green Party of Canada

3. Use the social scale or the economic scale to place the various political parties.

Be prepared to explain why you placed each one where you did.

\begin{tabular}{|lcr|}
\hline LW & Social & RW \\
\hline Social Scale & $\mathbf{I}$ & $\mathbf{I}$ \\
\hline
\end{tabular}

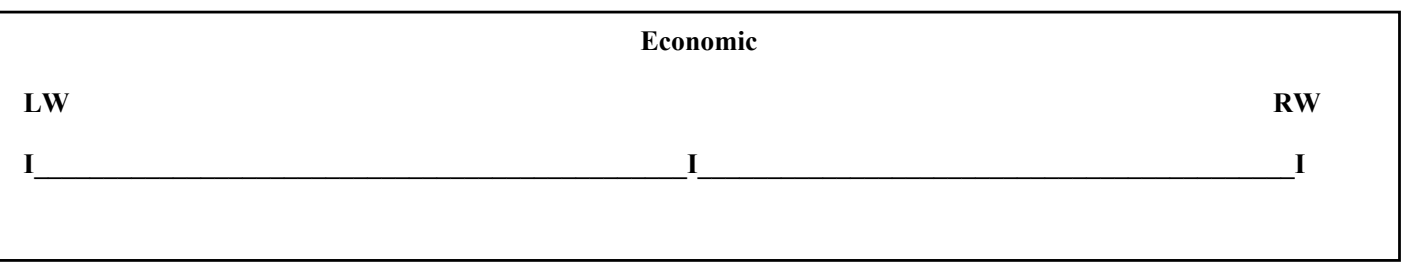

(i) The three American federal political parties

(ii) The five Canadian federal political parties

(iii) Using a separate set of axes to represent the economic and social scales, place the letter representing each of the following issues on one of the scales. Be prepared to explain why you placed each one where you did.

$$
\begin{aligned}
& \text { A - capital punishment } \\
& \text { B - increased rights of gay people } \\
& \text { C - allowing industry to self-regulate } \\
& \text { D - tax cuts for all }
\end{aligned}
$$


E - increased funding for public education

F - pro-life (on abortion issue)

$\mathrm{G}$ - pro-choice (on abortion issue)

$\mathrm{H}$ - government regulations of the financial industry

I - increased military spending

$\mathrm{J}$ - increased social welfare spending

$\mathrm{K}$ - publicly funded healthcare system

L - subsidized daycare

M - the UN's Universal Declaration of Human Rights

$\mathrm{N}$ - “pull yourself up by the bootstraps” philosophy

$\mathrm{O}$ - support for unions

$\mathrm{P}$ - banning sex education in schools

$\mathrm{Q}$ - increased support for Aboriginal land treaties

$\mathrm{R}$ - martial law

$\mathrm{S}$ - progressive tax reform (eg., raising taxes on large corporations)

$\mathrm{T}$ - support for replacement workers during a strike 